\title{
Victims' Justice? Reparations and Asset Forfeiture at the Extraordinary African Chambers
}

\section{Daley J Birkett*}

Walther Schücking Institute for International Law, University of Kiel Amsterdam Center for International Law, University of Amsterdam d.j.birkett@uva.nl

\begin{abstract}
This article critically analyses the reparations and asset forfeiture framework at the Extraordinary African Chambers and its application in the case against Hissène Habré. It identifies obstacles to implementing the reparations awarded and calls for states and international organizations to support their realization for the sake of Habré's victims, without whose efforts the tribunal might not exist. It argues that international(ized) criminal tribunals should more readily utilize fines and forfeiture as penalties to alleviate the pressure on trust funds to implement reparations awards, particularly in cases where convicted persons possess substantial assets. Lastly, in light of the requirement that assets susceptible to forfeiture orders be derived directly or indirectly from the crime(s) of which a person is found guilty, the article questions the failure of the prosecutor to charge Habre with the war crime of pillage, despite its availability in the tribunal's statute and the finding that the suffering of many of Habré's victims entitled to individual compensation resulted from pillage.
\end{abstract}

\section{Keywords}

Reparations, forfeiture of assets, Extraordinary African Chambers, Senegal, Hissène Habré, Chad

\section{FINANCING REPARATIONS AT INTERNATIONAL(IZED) CRIMINAL TRIBUNALS}

On 27 April 2017, the Appeals Chamber of the Extraordinary African Chambers (EAC) issued its judgment in the case against Hissène Habré, a

* LLB (Durham University), LLM (Leiden University). Research associate, Walther Schücking Institute for International Law, Faculty of Law, University of Kiel; research fellow, War Reparations Centre, Amsterdam Center for International Law, Faculty of Law, University of Amsterdam. The author wishes to thank Gregory Gordon, Larissa van den Herik, Nina Jørgensen, Denis Abels and Göran Sluiter for their comments on earlier drafts of this article. 
former president of Chad. ${ }^{1}$ In the appeal judgment, which confirmed his conviction for crimes against humanity, torture and war crimes, the Appeals Chamber also ordered Habré to pay compensation equivalent to more than USD 145 million to the victims of his crimes. ${ }^{2}$ This is the largest amount of compensation awarded against a convicted person by an international(ized) criminal tribunal (ICT) ${ }^{3}$ and, although significant for recognizing the vast harm suffered by Habré's victims, the award of such a huge sum presents a number of challenges, including how to finance the reparations awarded.

In light of the difficulties in funding organs established to administer reparations at ICTs, this article analyses the law and practice of the EAC, from which, it argues, lessons can be learned for the permanent International Criminal Court (ICC). The article questions why the EAC prosecutor failed to charge Hissène Habre with the war crime of pillage, despite its inclusion in the EAC's constituent instrument and in view of the requirement that assets susceptible to orders for forfeiture be derived directly or indirectly from the crime(s) of which a person is found guilty. Furthermore, the article argues that, in situations similar to that of Habré, where an accused or convicted person possesses (or is able to access) significant assets, ICTs ought to place greater emphasis on fines and the forfeiture of assets so as to reduce their reliance on voluntary donations to meet the cost of reparations. Finally, the article identifies the substantial pressure on the EAC Trust Fund (Trust Fund) to implement reparation awards ordered against Habré in the absence of sufficient assets to meet the entire compensation awarded.

Assets belonging to convicted persons can be used to finance reparations awarded to the victims of international crimes. ${ }^{4}$ As Nader Iskander Diab put it, "[t]he unavailability of assets is probably the greatest challenge in funding court ordered reparations. Due to their nature as the product of a court ruling, the obligation to fund them rests on the convicted person and stems from his / her civil responsibility for the harm caused". ${ }^{5}$ Without such assets, trust funds

1 Le Procureur Général v Hissein Habré Appeals Chamber, 27 April 2017 (appeal judgment).

2 Id at 226.

3 On 24 March 2017, the International Criminal Court Trial Chamber II issued an order for reparations against Germain Katanga, in which it found that, despite his indigence, he was liable for the sum of USD 1 million. See Prosecutor $v$ Germain Katanga, order for reparations pursuant to article 75 of the statute (ICC-01/04-01/07-3728-tENG) 24 March 2017 (Order for Reparations), para 264. On 8 March 2018, this was confirmed by the Appeals Chamber; see Prosecutor $v$ Germain Katanga, public redacted judgment on the appeals against the Order for Reparations (ICC-01/04-01/07-3778-Red) 8 March 2018, para 186.

4 This is explicitly recognized in art 79(2) of the Rome Statute of the International Criminal Court (ICC Statute): "The Court may order money and other property collected through fines or forfeiture to be transferred, by order of the Court, to the Trust Fund."

5 NI Diab "Challenges in the implementation of the reparation award against Hissein Habré: Can the spell of unenforceable awards across the globe be broken?" (2018) 16 Journal of International Criminal Justice 141 at 150. See also C Ferstman "Cooperation and the International Criminal Court: The freezing, seizing and transfer of assets for 
established to implement reparations awards, among other tasks, may not realize their objectives. The ICC is illustrative in this regard because its Trust Fund for Victims (TFV) largely relies on voluntary donations to meet its objectives. The TFV regulations provide that the body shall be funded from four sources: voluntary contributions; proceeds collected through fines or orders for forfeiture; resources drawn from reparations awards; and other funds allocated by the Assembly of States Parties. ${ }^{6}$ However, voluntary contributions are by no means reliable. For example, the TFV's financial statements for 2015 show that both voluntary contributions and, consequently, its fiscal surplus declined because of the financial pressure facing donors due to the arrival in Europe of large numbers of migrants and refugees. ${ }^{7}$ Reflecting on the challenges facing the TFV, Sara Kendall accurately observes that its reliance on voluntary donations is exacerbated by "its dual mandate of providing general assistance as well as dispensing court-ordered reparations following convictions", ${ }^{8}$ rendering its finances particularly tenuous.

Like a limited number of victim-oriented ICTs, ${ }^{9}$ the EAC has a reparations framework, pursuant to which compensation (reparations awards), among other measures, may be ordered directly against convicted persons. If the compensation is (partially) financed from the assets of the convicted person, the assets seized require no link to the crime(s) for which the person has been convicted. ${ }^{10}$ Orders for fines against a convicted person also require no such evidential connection. Conversely, only those assets derived directly or indirectly from the crime(s) of which a person is found guilty are susceptible to orders for forfeiture, thereby excluding other assets that do not have such a link to the offences. Reparations mechanisms cannot operate effectively without funds, nor, it is argued, should they be expected to bear this heavy burden in cases where a convicted person possesses substantial wealth. ${ }^{11}$

Several persons accused or convicted of genocide, crimes against humanity or war crimes have amassed substantial wealth, whether through the

contd

the purpose of reparations" in O Bekou and DJ Birkett (eds) Cooperation and the International Criminal Court: Perspectives from Theory and Practice (2016, Brill Nijhoff) 227 at 234 .

6 Reg 21 of the Regulations of the TFV, ICC-ASP/4/Res.3, annex (3 December 2005).

7 See "ASP 15th session: Financial statements of the Trust Fund for Victims for the year ended 31 December 2015”, ICC-ASP/15/13 (11 August 2016) at 21, available at: <http:// www.legal-tools.org/doc/55f6b0/> (last accessed 25 April 2019).

8 S Kendall "Commodifying global justice: Economies of accountability at the International Criminal Court" (2015) 13 Journal of International Criminal Justice 113 at 124.

9 These include the ICC, the Extraordinary Chambers in the Courts of Cambodia, and the Kosovo Specialist Chambers and Specialist Prosecutor's Office.

10 On which, see Ferstman "Cooperation and the International Criminal Court", above at note 5 at 234 .

11 On some of the difficulties faced in financing reparations awards when the convicted person is indigent, see Diab "Challenges in the implementation", above at note 5 at 150-57. 
commission of these crimes ${ }^{12}$ and / or by other, not necessarily criminal, means. ${ }^{13}$ Hissène Habré appears to fall into this category of affluent offenders. According to the Commission of Inquiry established by the new Chadian government following the dictator's fall from power, ${ }^{14}$ each year movable and immovable goods worth an estimated one billion CFA francs, ${ }^{15}$ were "plundered and confiscated from peaceful citizens" by the Habré regime. ${ }^{16}$ The commission's report further observes that most plundered goods of high value, including "deluxe carpets, vehicles, gold jewelry [sic], etc", were transferred to the presidency. ${ }^{17}$ Although this conduct is not necessarily connected, directly or indirectly, to the international crimes of which Habré was ultimately found guilty, their proceeds could form part of awards for reparations made against him following his conviction.

There are numerous potential obstacles to funding reparations awards with the assets of convicted persons, although these can arguably be overcome, except where the individual is deemed to be indigent. Diab identifies three such hurdles. ${ }^{18}$ First, there is a need for swift action by the relevant ICT. In the words of ICC Pre-Trial Chamber I, "existing technology makes it possible for a person to place most of his assets and moveable property beyond the Court's reach in only a few days". ${ }^{19}$ Further potential obstacles identified by Diab could arise from the legal framework(s) applicable in the state(s) in which the assets are held ${ }^{20}$ and a lack of asset tracing capability at ICTs. It is difficult to contest the former, although it is noted with regard to the ICC

12 See M Galvis Martínez "Forfeiture of assets at the International Criminal Court: The short arm of international criminal justice” (2014) 12 Journal of International Criminal Justice 193 at 195-204. Galvis Martínez identifies enslavement, sexual exploitation, the taking of hostages, pillaging and the unlawful appropriation, seizure or destruction of property as potentially lucrative international crimes.

13 For example, at the time of his first appearance before the ICC, Jean-Pierre Bemba Gombo is reported to have owned "a large business empire": see M Simons "Jean-Pierre Bemba, Congolese politician, appears in Hague court" (4 July 2008) The New York Times at A5. It is noted, however, that the ICC Appeals Chamber acquitted Mr Bemba of war crimes and crimes against humanity on 8 June 2018. See Prosecutor $v$ Jean-Pierre Bemba Gombo, judgment on the appeal of Mr Jean-Pierre Bemba Gombo against Trial Chamber III's judgment pursuant to article 74 of the statute (ICC-01/05-01/08-3636-Red) 8 June 2018.

14 Commission of Inquiry Chad: Report of the Commission of Inquiry into the Crimes and Misappropriations Committed by Ex-President Habré, his Accomplices, and / or Accessories: Investigation of Crimes Against the Physical and Mental Integrity of Persons and their Possessions (7 May 1992), available at: <http://www.usip.org/files/file/resources/collections/commissions/ Chad-Report.pdf> (last accessed 25 April 2019) (Chad Report).

15 At the time of writing, equivalent to more than USD 1.75 million.

16 Chad Report, above at note 14 at 92.

17 Id at 82.

18 Diab "Challenges in the implementation", above at note 5 at 153-54.

19 Prosecutor $v$ Thomas Lubanga Dyilo, decision concerning Pre-Trial Chamber I's decision of 10 February 2006 and the incorporation of documents into the record of the case against Mr Thomas Lubanga Dyilo (ICC-01/04-01/06-8-Corr) 24 February 2006, para 137.

Diab "Challenges in the implementation", above at note 5 at 153. 
that state parties to the court's constituent instrument are under an obligation to "ensure that there are procedures available under their national law for all of the forms of cooperation" specified under part IX. ${ }^{21}$ This extends to the "identification, tracing and freezing or seizure of proceeds, property and assets and instrumentalities of crimes for the purpose of eventual forfeiture" under article 93(1)(k) of the court's statute. Should a state's legal framework prove problematic in this respect, then that state's legislature could revise, for example, onerous requirements pertaining to the provisional freezing of assets in core international crimes cases. The ICC has explicitly discussed the idea of state parties adjusting their domestic cooperation laws for such purposes. ${ }^{22}$ Otherwise, or additionally, as Diab acknowledges, ${ }^{23}$ asset-tracing expertise could be sought in the form of financial investigators. As for in-house expertise, the ICC employs dedicated financial investigators in its Registry and Office of the Prosecutor; it has, however, been observed that such resources are limited at both court and state party levels and that further specialist training and resources would be welcome to strengthen the ICC's capacity to conduct successful financial investigations. ${ }^{24}$

\section{THE REPARATIONS AND FORFEITURE FRAMEWORK IN THE EAC STATUTE}

In 2012, the African Union and the Republic of Senegal established the EAC within the Senegalese court system to try international crimes committed in Chad between 7 June 1982 and 1 December 1990.25 That agreement was the fruit of more than two decades of victim and civil society advocacy, litigation at the International Court of Justice and the Court of Justice of the Economic Community of West African States, as well as negotiations between the African Union and the Senegalese government. It is beyond the scope of this article to recount the history of the tribunal, which has been considered

21 ICC Statute, above at note 4 , art 88.

22 See ICC "Report on cooperation challenges faced by the court with respect to financial investigations: Workshop 26-27 October 2015, The Hague, Netherlands: Forward-looking conclusions" (October 2015) at 3, available at: <https://www.icc-cpi.int/iccdocs/other/161027-ICCRep-Eng.pdf> (last accessed 25 April 2019): "States Parties have an obligation to adopt procedures that facilitate the implementation of all forms of cooperation requests including in the area of financial investigations (article 93(1)(k) of the Rome Statue [sic]). As financial investigations are becoming an increasingly important part of the Court's work, States Parties should ensure that they are able to 'fully cooperate' in this area." (emphasis original). Diab "Challenges in the implementation", above at note 5 at 153.

24 ICC "Report on cooperation challenges", above at note 22 at 7.

25 Agreement Between the Government of the Republic of Senegal and the African Union on the Establishment of Extraordinary African Chambers in the Senegalese Courts, available in French in African Yearbook of International Law Online / Annuaire Africain de Droit International Online (2011, Brill / Nijhoff) at 403-10 and in English, id at 437-42. 
at length elsewhere. ${ }^{26}$ Nevertheless, the vital role played by victims' groups and civil society organizations in establishing the EAC is particularly noteworthy.

The participation of victims as civil parties to proceedings before the tribunal is regulated by the EAC Statute ${ }^{27}$ and, as a tribunal housed within the Senegalese legal system, the Senegalese Code of Criminal Procedure. ${ }^{28}$ Pursuant to these documents, victims may ask to participate as civil parties at any stage of the investigation. ${ }^{29}$ The EAC is also empowered to order reparations measures in accordance with article 27(1) of the EAC Statute, namely restitution, compensation, and rehabilitation.

With regard to reparations awards for compensation, the EAC may order ${ }^{30}$ that such measures be implemented by the Trust Fund established under article 28 of the EAC Statute for the benefit of victims of the crimes within the jurisdiction of the EAC and their beneficiaries. ${ }^{31}$ Article 28 further provides that the Trust Fund is to be financed by voluntary contributions from foreign governments, international institutions, non-governmental organizations and other sources willing to support the victims. ${ }^{32}$ Finally in this regard, the EAC Statute does not limit reparations awards to registered civil parties; rather, it provides that reparations may be awarded to victims, individually or collectively, whether or not they have participated in proceedings before the EAC. ${ }^{33}$

Notably, however, the EAC Statute does not include a provision akin to article 79(2) of the ICC Statute, which allows the ICC to order the transfer of proceeds collected through forfeiture and / or fines to the TFV, or similar to article 44 of the law on the establishment of the Kosovo Specialist Chambers

See S Williams "The Extraordinary African Chambers in the Senegalese courts: An African solution to an African problem?" (2013) 11 Journal of International Criminal Justice 1139; E Cimiotta "The first steps of the Extraordinary African Chambers new mixed criminal tribunal?" (2015) 13 Journal of International Criminal Justice 177; R Brody "Bringing a dictator to justice: The case of Hissène Habré" (2015) 13 Journal of International Criminal Justice 209. V Spiga "Non-retroactivity of criminal law: A new chapter in the Hissène Habré saga” (2011) 9 Journal of International Criminal Justice 5.

Statute of the Extraordinary African Chambers in the Senegalese Courts for the Prosecution of International Crimes Committed in Chad between 7 June 1982 and 1 December 1990 (EAC Statute), available in French at African Yearbook, above at note 25 at 411-26 and in English, id at 443-58.

28 Id, art 14(5). See also Cimiotta "The first steps", above at note 26 at 188; M Fall "The Extraordinary African Chambers: The case of Hissène Habré" in G Werle, L Fernandez and M Vormbaum (eds) Africa and the International Criminal Court (2014, TMC Asser Press) 117 at 123.

29 EAC Statute, ibid.

30 Id, art 27(2).

31 Id, art 28(1).

32 Ibid.

33 Id, art 28(2). 
and Specialist Prosecutor's Office, ${ }^{34}$ which explicitly permits the tribunal to order the sale of forfeited assets to finance reparation awards. ${ }^{35}$

Turning to penalties, the EAC is empowered to order fines in accordance with the criteria provided under Senegalese law. ${ }^{36}$ Pursuant to article 24(2) of the EAC Statute, the EAC is also able to order, as a penalty in addition to imprisonment, forfeiture of proceeds, property and assets derived directly or indirectly from crime(s) for which a person is convicted. The EAC Statute further provides that it is the responsibility of the state authorities in whose territory such property and assets are located to enforce any forfeiture measures requested. ${ }^{37}$ Furthermore, according to article 87 bis of the Senegalese Code of Criminal Procedure, the EAC is empowered to order protective, pre-conviction measures in respect of the assets of an accused person. ${ }^{38}$

\section{REPARATIONS AWARDS AND FORFEITURE MEASURES AGAINST HISSĖNE HABRÉ}

On 30 May 2016, the EAC Trial Chamber issued its judgment in the case against Hissène Habré, in which it found him guilty of crimes against humanity, the crime of torture and war crimes, and sentenced him to life imprisonment. ${ }^{39}$ On 29 July 2016, the Trial Chamber handed down a further decision concerning reparations, ${ }^{40}$ in which it awarded 20 million CFA francs to each victim of rape and sexual slavery, 15 million CFA francs to prisoners of war and victims of arbitrary detention, torture and other inhumane treatment, and 10 million CFA francs to each indirect victim. ${ }^{41}$ These sums fell significantly short of the amounts requested by the first two victim groups. ${ }^{42}$ The Trial Chamber also refused the civil parties' request to grant collective reparations. ${ }^{43}$ On 4 and 5 August 2016, respectively, the civil parties' representatives filed appeals against the decision on reparations with respect to several issues.

34 Law No 05/L-053 of 3 August 2015, available at: <https://www.kuvendikosoves. org/common/docs/ligjet/05-L-053\%20a.pdf> (last accessed 25 April 2019).

35 Id, art 44(6).

36 EAC Statute, above at note 27, art 24(1).

37 Id, art 26(5).

38 Art 87 bis provides: "When in receipt of a case file, the investigating judge can, on his own initiative or at the request of a civil party or the prosecution, order protective measures in respect of the accused's assets." (author's translation).

39 Judgment in Ministère Public v Hissein Habré Trial Chamber, 30 May 2016 (trial judgment).

40 Ministère Public v Hissein Habré Trial Chamber, 29 July 2016 (decision on reparations).

41 Id, para 82. At the time of writing, 20 million CFA francs is equivalent to approximately USD 35,000, 15 million CFA francs is equivalent to approximately USD 26,500, and 10 million CFA francs is equivalent to approximately USD 17,500 .

42 Victims of rape had sought 60 million CFA francs, victims of sexual slavery 75 million CFA francs, and victims of arbitrary detention, torture and other inhumane treatment 50 million CFA francs.

43 Decision on reparations, above at note 40 , para 82. 
On 27 April 2017, the EAC Appeals Chamber issued its judgment, in which it addressed, inter alia, the issues raised on appeal by the civil parties' representatives. ${ }^{44}$ Notably, the Appeals Chamber fixed the total amount of reparations payable to civil parties at over 82 billion CFA francs and sentenced Habré to pay this amount. ${ }^{45}$ The Appeals Chamber further held that, at the time it issued its judgment, Habré's assets were insufficient to cover the totality of the individual reparations awarded. ${ }^{46}$ The Appeals Chamber made a number of additional significant orders in its judgment. First, it demanded that the proceeds of all property that had already been seized, as well as any assets belonging to Hissène Habré discovered in the future, be paid into the Trust Fund to finance the reparations awards ordered. ${ }^{47}$ Secondly, the Appeals Chamber instructed the Trust Fund continually to monitor Habré's financial situation with a view to identifying, freezing and seizing any proceeds of crimes, property or assets. ${ }^{48}$ The Appeals Chamber further invited interested states to cooperate with the Trust Fund to guarantee the realization of the individual reparations awarded and the eventual implementation of a programme of collective reparations. ${ }^{49}$ Finally, the Appeals Chamber encouraged the Trust Fund to contact the Chadian government as well as interested states, organizations and civil society associations with respect to implementing collective and moral reparations. ${ }^{50}$

With regard to asset forfeiture measures, the Trial Chamber had rejected the prosecutor's request to impose such a penalty as neither justified nor well founded. ${ }^{51}$ Furthermore, the Trial Chamber observed that the EAC Investigative Chamber had seized assets belonging to Hissène Habré as a protective measure to preserve the interests of civil parties to the proceedings and that the prosecutor had failed to demonstrate that such assets resulted, directly or indirectly, from the commission of his crimes. ${ }^{52}$ The Appeals Chamber did not reverse the Trial Chamber's finding.

The failure to secure a forfeiture order in this case can be attributed to the difficulties facing the prosecutor in meeting the evidentiary threshold, namely that any proceeds, property and / or assets be derived directly or indirectly from the crime(s) for which a person is convicted. ${ }^{53}$ This begs the

53 See C McCarthy Reparations and Victim Support in the International Criminal Court (2012, Cambridge University Press) at 199-202. 
question as to why Hissène Habré was not charged with the war crime of pillage pursuant to article 7(2)(f) of the EAC Statute. The Appeals Chamber held that the prejudice suffered by a substantial number of Habré's victims included pillage, ${ }^{54}$ but no such charge was brought to the attention of the Trial Chamber for its determination. Although the prosecutor undoubtedly has discretion with respect to the charges brought against an accused person, surely the indictment ought to reflect fairly the (at this stage of the proceedings, alleged) harm suffered by victims of the conduct under investigation. Given that, in determining reparations, the Appeals Chamber found such a large number of victims to have suffered from pillage, often in conjunction with crimes for which Habré was convicted, the charges included in the indictment do not appear to represent fairly the harm suffered. The Appeals Chamber's order that victims who experienced pillage are entitled to compensation is also difficult to reconcile with the Trial Chamber's earlier finding in its decision on reparations that victim status is tied to the crimes for which Habré was convicted. 55

Another charge that could have been levied by the prosecutor was the extensive destruction and appropriation of property, not justified by military necessity and carried out unlawfully and wantonly, under article 7(1)(c) of the EAC Statute. In its order, inter alia, committing the case to trial, ${ }^{56}$ the Investigative Chamber noted that the prosecutor referred to this offence in his opening submission, but failed to refer to it in his final submission. ${ }^{57}$ This led the Investigative Chamber to rule on the matter, finding that, if individuals were indeed victims of the "pillage" of their property, the circumstances in which those acts were allegedly committed precluded the chamber from considering the crime. ${ }^{58}$ According to the Investigative Chamber, these "circumstances" included its finding that the conduct did not take place in the context of an armed conflict, as required by the elements of a war crime. ${ }^{59}$ The Investigative Chamber made no such determination with regard to pillage.

Equally, the absence of a forfeiture order against Hissène Habré could result from a dearth of identified assets. Diab identifies a lack of effort to locate and freeze Habré's assets before or during the proceedings, ${ }^{60}$ but this fails to take

54 See appeal judgment, above at note 1 , annex.

55 Decision on reparations, above at note 40 , para 3.

56 Order for partial dismissal, indictment and remand to the Trial Chamber of the Extraordinary African Chambers, Investigative Chamber, 13 February 2015 (Investigative Chamber order).

57 Id at 122.

58 Id at 123. It is noted that the French "pillage" can be translated to mean looting or pillage. It is, however, argued that, to avoid confusion with the specific legal meaning afforded to the war crime of pillage, the Investigative Chamber ought to have referred only to alleged incidents of appropriation of property: appropriation de biens.

59 Investigative Chamber order, above at note 56 at 123.

60 Diab "Challenges in the implementation", above at note 5 at 153. 
into account that, during the investigation, the Investigative Chamber ordered protective measures, ${ }^{61}$ pursuant to which two bank accounts and one piece of real property in Habré's name were frozen. ${ }^{62}$ However, no further assets have been located, a fact about which civil society organizations expressed concern after the delivery of the appeal judgment. ${ }^{63}$ This scarcity of assets also affects the capacity of the Trust Fund to enforce the reparations awards ordered by the EAC.

\section{CONCLUDING REMARKS}

The EAC Appeals Chamber's award of compensation equivalent to more than USD 145 million to the victims of Hissène Habré's crimes was a landmark decision recognizing the harm they suffered during his reign of terror in Chad. At the same time, the implementation of such awards presents significant challenges for the EAC (and other ICTs) even in cases where convicted persons possess substantial assets. This is not to say that significant awards for reparations should not be made against indigent accused; indeed, the majority of persons convicted of international crimes have been found to be indigent. Rather, this article has sought to shed light upon the difficulties in financing such awards, proposing that fines and forfeiture of assets could provide useful vehicles to secure funding in certain cases.

Although fines and assets forfeited by persons convicted of international crimes are unlikely to satisfy reparation awards for compensation fully, ${ }^{64}$ they provide an avenue through which trust funds established at ICTs, ${ }^{65}$ including the TFV at the permanent ICC, might secure much-needed resources to realize their respective mandates. Further, although reparation awards may be made directly against persons convicted of international crimes, such measures do not fulfil the corrective function attributable to asset forfeiture as a penalty in the constituent instruments of ICTs. ${ }^{66}$

61 Order for protective measures, Investigative Chamber, 29 October 2013.

62 Appeal judgment, above at note 1 at 296.

63 See for example Amnesty International "Chad: Hissène Habré appeal ruling closes dark chapter for victims" (27 April 2017), available at: <https://www.amnesty.org/en/pressreleases/2017/04/chad-hissene-habre-appeal-ruling-closes-dark-chapter-for-victims/> (last accessed 25 April 2019).

64 A possible, albeit hypothetical, exception could have been Muammar Gaddafi, whose net worth at the time of his death is reported to have been in excess of USD 200 billion. See P Richter "As Libyans take stock: Moammar Kadafi's hidden riches astound" (22 October 2011) Los Angeles Times, available at: <http://articles.latimes.com/2011/oct/21/world/ la-fg-kadafi-money-20111022> (last accessed 25 April 2019).

65 On the EAC as an ICT, see Williams "The Extraordinary African Chambers", above at note 26 at 1144-47. Compare with Cimiotta "The first steps", above at note 26 at 189-97.

66 See R Young "Fines and forfeiture in international criminal justice" in R Mulgew and D Abels (eds) Research Handbook on the International Penal System (2016, Edward Elgar) 102 at 109. 
In cases where the convicted persons are not deemed indigent, asset recovery is crucial to give effect to both reparations awards mandated against them as well as any fines and / or orders for the forfeiture of assets. Without such assets, ICT trust funds are largely reliant on voluntary donations to operationalize reparations awards and fines, and forfeiture orders are difficult, if not impossible, to enforce. In the case against Hissène Habré, although there was no order for asset forfeiture as a penalty additional to imprisonment, the EAC awarded significant reparations to his victims. In order that these awards might be implemented, and victims might receive the compensation to which they are entitled, it is critical that states and international organizations work to identify, trace, freeze and seize proceeds, property and assets belonging to Habré. Diab identifies the need for publicity of the case in this context, arguing that prominent cases "are more likely to translate into practical and legal steps meant to assist in the process of repatriating assets" ${ }^{67}$ It was, in part, the victims' tenacity that led to the establishment of the EAC. Notwithstanding the potential obstacles, it is consequently imperative that Hissène Habré's outstanding assets be recovered and transferred to the victims, as intended in accordance with the awards made.

67 Diab "Challenges in the implementation", above at note 5 at 154. In this respect, Diab suggests (at 155) a potential role for investigative journalists: "Even in the event that the information obtained by journalists would not be admissible in court, having leads as to the location of assets could increase pressure on states to further investigate and proceed to freezing and repatriation of assets." 